\title{
Breast abscess due to Salmonella species: a brief review of epidemiology, clinical manifestations, serological correlation and management
}

\author{
Kinjal P. Patel*, Rutuja Darne, Reshma Poojary, Virendra Kinjale
}

Department of Laboratory Medicine, Apoorva Diagnostics and healthcare, Thane, Maharashtra, India

Received: 02 December 2020

Accepted: 05 March 2021

\section{*Correspondence:}

Dr. Kinjal P. Patel,

E-mail: kinjal.1527@gmail.com

Copyright: ( ) the author(s), publisher and licensee Medip Academy. This is an open-access article distributed under the terms of the Creative Commons Attribution Non-Commercial License, which permits unrestricted non-commercial use, distribution, and reproduction in any medium, provided the original work is properly cited.

\begin{abstract}
Breast abscess due to Salmonella is an uncommon but well recognized extra-intestinal complication of enteric fever. Salmonella species is commonly identified as a gastrointestinal pathogen causing bacteremia but inappropriately treated cases can led to dissemination in multiple organ systems resulting in localized abscess formation. Case reports have been described in literature about extra-intestinal abscesses by both $S$. enterica serotype typhi and paratyphi. Whilst recently, there has been an upsurge in the frequency of case reports related to Salmonella breast abscess, reason may be due to emergence of resistant Salmonella strains. Usually uncomplicated abscesses show effective clearance with single course of oral antibiotic agents together with surgery. Reviews have recommended azithromycin as a drug of choice especially in the presence of fluoroquinolones resistance. So, acknowledging prevalence of breast abscess due to salmonella is utmost important.
\end{abstract}

Keywords: Breast, Abscess, Salmonella, Clinical features, Serology, Treatment

\section{INTRODUCTION}

Breast abscess is a localized, painful collection of purulent material in breast tissue mostly affecting women of reproductive age group. They are predominantly lactational but non-lactational abscesses are also seen in premenopausal older women. Although Staphylococcus aureus is the most common pathogen, other microorganisms can be found for example Streptococcus species, coagulase negative Staphylococcus and anaerobes such as Peptostreptococccus and Bacteroides. ${ }^{1}$ Recent studies and various case reports highlighting breast abscess due to Salmonella spp. has been noted. In developing countries where enteric fever is endemic, Salmonella should be considered one of the main causes of breast abscess and treatment line should be decided accordingly. This review aims to summarize the available various case reports studies related to breast abscess due to Salmonella spp.

\section{EPIDEMIOLOGY OF BREAST ABSCESSES}

Although Staphylococcus aureus is the commonest pathogen but the incidence of Salmonella breast abscesses have been reported in up to $0.9 \%$ of cases. ${ }^{2}$ Salmonella species are majorly responsible for significant morbidity and mortality in developing countries. It is capable of forming localized abscesses in various organs such as subcutaneous tissue, muscles and skin. The pathogenesis of is not well established but possible causes may be hematogenous route and lymphatic spread from gastrointestinal tract. The major risk factors are extremes of ages, immune suppression, underlying malignancy, intravenous drug abuse and previous trauma. ${ }^{3}$ On analyzing the literature available on breast abscesses due to Salmonella spp., it was noted that most of the patients were immunocompetent non lactating females between the age group of 23-45 years. ${ }^{4}$ 
Table 1: Reported cases of breast abscess due to Salmonella typhi and paratyphi.

\begin{tabular}{|c|c|c|c|c|c|c|}
\hline $\begin{array}{l}\text { Ref. } \\
\text { no. }\end{array}$ & $\begin{array}{l}\text { Age } \\
(\text { years }) / \text { sex }\end{array}$ & Clinical features & Culture & Serology & Treatment & Follow up \\
\hline 5 & $40 / \mathrm{F}$ & $\begin{array}{l}\text { c/o fibroadenoma, lump in } \\
\text { breast since } 2 \text { months. }\end{array}$ & $\begin{array}{l}\text { S. typhi, } \\
\text { stool culture } \\
\text { grew } \\
\text { S. typhi }\end{array}$ & $\begin{array}{l}\text { TO 1:640, } \\
\text { TH 1:320 }\end{array}$ & $\begin{array}{l}\text { Ciprofloxacin (IV } \\
\text { then switched to } \\
\text { oral) }\end{array}$ & $\begin{array}{l}\text { Regression of } \\
\text { lesion }\end{array}$ \\
\hline 6 & $42 / \mathrm{F}$ & $\begin{array}{l}\text { High grade fever with } \\
\text { swelling since } 15 \text { days. }\end{array}$ & S. typhi & $\begin{array}{l}\text { TO } 1: 120, \text { TH } \\
1: 120\end{array}$ & $\begin{array}{l}\text { Oral ciprofloxacin } \\
\mathrm{BD} \text { for } 14 \text { days }\end{array}$ & $\begin{array}{l}\text { Cyst size } \\
\text { reduced and } \\
\text { excised }\end{array}$ \\
\hline 7 & $35 / \mathrm{F}$ & $\begin{array}{l}\text { Diabetic, Bilateral painful } \\
\text { swelling, low grade fever } \\
\text { since } 15 \text { days. }\end{array}$ & S. typhi & $\begin{array}{l}\text { TO 1:160, } \\
\text { TH 1:160 }\end{array}$ & $\begin{array}{l}\text { Cefotaxime (1 gm, } \\
8 \text { hourly) and } \\
\text { later switched over } \\
\text { to oral } \\
\text { amoxy/clavulanic } \\
\text { acid ( } 625 \mathrm{mg} \\
\text { tablet, thrice daily) }\end{array}$ & $\begin{array}{l}\text { Responded to } \\
\text { therapy }\end{array}$ \\
\hline 8 & $29 / \mathrm{F}$ & $\begin{array}{l}\text { Bilateral painful lump for } \\
\text { 7days, fever since } 1.5 \\
\text { month. Blood culture } \\
\text { grew } S . \text { typhi, treatment } \\
\text { not taken }\end{array}$ & S. typhi & $\begin{array}{l}\text { TO } 1: 160 \text { and } \\
\text { TH } 1: 40, \mathrm{AH} \\
1: 40 .\end{array}$ & $\begin{array}{l}\text { Oral ciprofloxacin } \\
500 \mathrm{mg} \text { bid for } 2 \\
\text { weeks }\end{array}$ & $\begin{array}{l}\text { Regression of } \\
\text { the lesion. } \\
\text { Cultures } \\
\text { negative on } \\
\text { subsequent } \\
\text { visits. }\end{array}$ \\
\hline 3 & $70 / \mathrm{M}$ & $\begin{array}{l}\text { Diabetic, swelling in } \\
\text { breast since } 9 \text { months, } \\
\text { P/h/o severe } \\
\text { gastroenteritis } 10 \text { months } \\
\text { back, no antibiotics taken. }\end{array}$ & $\begin{array}{l}\text { Salmonella } \\
\text { enterica } \\
\text { serotype } \\
\text { enteritidis }\end{array}$ & - & Oral ciprofloxacin & $\begin{array}{l}\text { Complete } \\
\text { resolution }\end{array}$ \\
\hline 9 & $33 / \mathrm{F}$ & $\begin{array}{l}\text { Painful lump, recurrent } \\
\text { abscess. }\end{array}$ & $\begin{array}{l}\text { S. paratyphi } \\
\text { A }\end{array}$ & - & $\begin{array}{l}\text { IV ceftriaxone } \\
\text { prolonged course }\end{array}$ & $\begin{array}{l}\text { Patient } \\
\text { responded well }\end{array}$ \\
\hline 10 & $33 / \mathrm{F}$ & Painful swelling. & $\begin{array}{l}\text { S. paratyphi } \\
A\end{array}$ & $\begin{array}{l}\text { TO }<1: 40, \\
\text { TH }<1: 40, \\
\text { AH }<1: 160, \\
\text { BH }<1: 40\end{array}$ & $\begin{array}{l}\text { Ceftriaxone for } 2 \\
\text { weeks }\end{array}$ & $\begin{array}{l}\text { Healing after } 3 \\
\text { weeks }\end{array}$ \\
\hline 11 & $40 / \mathrm{F}$ & $\begin{array}{l}\text { Pain and swelling in } \\
\text { breast since } 10 \text { days, } \\
\text { diarrhoea } 10 \text { days before } \\
\text { swelling. }\end{array}$ & S. typhi & $\begin{array}{l}\text { TO } 1: 80 \text { and } \\
\text { TH }=1: 320\end{array}$ & $\begin{array}{l}\text { Oral ciprofloxacin } \\
500 \text { mg bid for } 2 \\
\text { weeks along with } \\
\text { surgical } \\
\text { debridement }\end{array}$ & $\begin{array}{l}\text { Complete } \\
\text { healing after } 1 \\
\text { month }\end{array}$ \\
\hline 12 & $60 / \mathrm{F}$ & $\begin{array}{l}\text { Diabetic, fever since } 3 \\
\text { days, painful swelling in } \\
\text { breast. }\end{array}$ & S. typhi & $\begin{array}{l}\text { TO } 1: 80, \\
\text { TH } 1: 40 \mathrm{AH} \\
\text { and } \mathrm{BH}< \\
1: 20\end{array}$ & $\begin{array}{l}\text { Ceforperazone-, } \\
\text { salbactum } 500 \mathrm{mg} \\
\text { and Amikacin } 1 \mathrm{~g} \\
\text { tice daily for a } \\
\text { week }\end{array}$ & $\begin{array}{l}\text { Improved and } \\
\text { discharged on } \\
\text { oral cefixime } \\
\text { 200mg twice } \\
\text { daily for } 7 \\
\text { days. }\end{array}$ \\
\hline 13 & $37 / \mathrm{F}$ & $\begin{array}{l}\text { Diabetic, fever and painful } \\
\text { lump. }\end{array}$ & $\begin{array}{l}\text { S. paratyphi } \\
A\end{array}$ & $\begin{array}{l}\text { Widal test } \\
\text { negative }\end{array}$ & IV ceftriaxone & $\begin{array}{l}\text { Complete } \\
\text { resolution after } \\
10 \text { days }\end{array}$ \\
\hline 14 & $43 / \mathrm{F}$ & $\begin{array}{l}\text { c/o RA, fever, mild pain } \\
\text { and lump in breast }\end{array}$ & $\begin{array}{l}\text { S. enterica } \\
\text { serotype } \\
\text { typhimurium }\end{array}$ & $\begin{array}{l}\text { Widal test } \\
\text { negative }\end{array}$ & $\begin{array}{l}\text { Oral ciprofloxacin } \\
500 \mathrm{mg} \mathrm{BD}\end{array}$ & $\begin{array}{l}\text { Complete } \\
\text { healing by } 2 \\
\text { weeks. }\end{array}$ \\
\hline 15 & $60 / \mathrm{F}$ & $\begin{array}{l}\text { Diabetic, painful swelling } \\
\text { in breast. }\end{array}$ & S. typhi & $\begin{array}{l}\text { TO1:40, } \\
\text { TH 1:80 }\end{array}$ & - & $\begin{array}{l}\text { Wound healed } \\
\text { in } 10 \text { days }\end{array}$ \\
\hline 16 & $27 / \mathrm{F}$ & Unilateral, lump in breast. & $\begin{array}{l}\text { S. paratyphi } \\
A\end{array}$ & $\begin{array}{l}\text { Widal test } \\
\text { negative }\end{array}$ & $\begin{array}{l}\text { Oral azithromycin } \\
1 \text { gm OD for } 5 \\
\text { days, IV } \\
\text { ceftriaxone } 2 \mathrm{~g} \mathrm{BD} \\
\text { for seven days }\end{array}$ & $\begin{array}{l}\text { Complete } \\
\text { resolution in } \\
\text { both cases }\end{array}$ \\
\hline
\end{tabular}


On Analyzing the incidence of breast abscess in typhoid patients has been observed as $0.3 \%$ in 1930 by Klose and Sebening and $0.5 \%$ in 1937 by Pezinski in a study of 1,196 cases of typhoid over a period of 2 years. Other authors have also reported similar cases of unilateral breast abscess due to Salmonella typhi as well as bilateral breast abscesses. Cases were also found from countries like france and USA (Table 1). ${ }^{4-18}$ Unlike Salmonella typhi, breast abscess due to Salmonella paratyphi is a rare complication of enteric fever. Fernando et al had reported the first case of recurrent breast abscess caused by Salmonella enterica serotype paratyphi A while Siddesh et al reported a chronic case of breast abscess by Salmonella Paratyphi $A$ in India from Mysore. Ghadage et al had reported a case of recurrent breast abscess Salmonella paratyphi $A$ in a 31 year old non lactating female.

Among non typhoidal salmonellae, Razeq et al and Edelstein et al had isolated Salmonella landweisser and Salmonella serogroup $B$ respectively. Benwan et al reported a very rare serotype, Salmonella enterica serotype Poona, which was associated with erythema nodosum. Kumar et al reported a multidrug-resistant typhoid with breast abscess. Elumalai et al analyzed the fluoroquinolones resistance mechanism in $S$. typhi from a breast abscess case, which is rare and uncommon. The $S$. typhi isolate showed high level resistance to nalidixic acid; minimum inhibitory concentration (MIC) $>512$ $\mu \mathrm{g} / \mathrm{ml}$ ) and ciprofloxacin (MIC $8 \mu \mathrm{g} / \mathrm{ml}) .{ }^{11-18}$

Hence, any breast abscess in an immunocompetent female with or without a history of enteric fever and no other predisposing factors must be evaluated, keeping the possibility of a Salmonella breast abscess. The pus aspirated must be sent for bacteriological culture. If not done, such diagnosis could be easily missed.

\section{CONCLUSION}

This review highlights the need for understanding the local epidemiology of enteric fever and its complications. Complete assessment of the patient including breast imaging, microbiological culture, and drug susceptibility report are essential for appropriate management of rare complications of enteric fever like breast abscesses. Clinicians must be aware of the management and should make referrals for any patient for which resolution does not occur rapidly with a single course of antibiotic therapy. Delay in such issues can have serious consequences on residual morbidity.

Funding: No funding sources Conflict of interest: None declared Ethical approval: Not required

\section{REFERENCES}

1. Dixon JM. Breast infection. In: Dixon JM, eds. ABC of breast diseases. 3rd ed. Oxford, England: Blackwell; 2006:19-23.

2. Edelstein H. 1993. Breast abscess due to Salmonella serogroup B, serotype Reading, in a young nonpuerperal woman. Clin Infect Dis. 2015;17:9512.

3. Brncic N, Gorup L, Strcic M, Abram M, Mustac E. Breast abscess in a man due to Salmonella enterica serotype Enteritidis. J Clin Microbiol. 2012;50(1):192-3.

4. Lalitha MK, John R .Unusual manifestations of Salmonellosis-a surgical problem. Q J Med. 1994;87:301-9.

5. Jayakumar K, Appalaraju B, Govindan VK. An atypical presentation of Salmonella typhi - A case report. Indian J Med Microbiol. 2003;21: 211-2.

6. Viswanathan R, Shah Ah, Nagori IF, Gupta MK. Salmonella typhi in breast abscess Case reports. Bombay Hospital J. 2003;45(3):58-65.

7. Singh S, Pandya Y, Rathod J, Trivedi S. Bilateral breast abscess: A rare complication of enteric fever. Indian J Med Microbiol. 2009;27: 69-70.

8. Singh G, Dasgupta M, Gautam V, Behera A, Ray P. Bilateral breast abscesses due to Salmonella Enterica Serotype Typhi. J Glob Infect Dis. 2011;3:402-4.

9. Fernando S, Molland JG, Gottlieb T. Failure of oral antibiotic therapy, including azithromycin, in the treatment of a recurrent breast abscess caused by Salmonella enterica serotype Paratyphi A. Pathog Glob Health. 2012;106:366-9.

10. Siddesh G, Sumana MN. A case of breast abscess due to Salmonella Paratyphi A. Int J Health Allied Sci. 2012;1:109-11.

11. Banu A, Hassan MM, Anand M. Breast abscess: Sole manifestation of Salmonella typhi infection. Indian J Med Microbiol. 2013;31:94-5.

12. Kumar ES, Selvam RE, Ramesh SS. Salmonella enterica serovar Typhi in breast abscess: A case report. Indian J Pathol Microbiol. 2012;55:608-9.

13. Sood S. Breast abscess by Salmonella Paratyphi A: Case report and literature review. J Clin Diagn Res. 2015;9:DD03-4.

14. Irmak B, Neriman A, Altan A. Breast abscess due to Salmonella Typhimurium in a patient with rheumatoid arthritis: a case report. BMC Infect Dis.2016;16:348.

15. Murugesan N, Alagar samy R, Viswanathan MS, Anbazhagan A. A rare case of breast abscess due to Salmonella Typhi. IJCRR. 2016;8:10-2.

16. Agrawal S, Yadav VS, Srivastava A, Kapil A, Dhawan B. Breast abscess due to Salmonella paratyphi A: Case reports with review of literature. Intractable Rare Dis Res. 2018;7(2): 130-3.

17. Delori M, Abgueguen P, Chennebault JM, Pichard E, Fanello S. Breast abscess with Salmonella typhi and review of the literature. J Gynecol Obstet Biol Reprod (Paris). 2007;36: 709-12. 
18. Vattipally V, Thatigotla B, Nagpal K, Saraiya R, Henry M, Shah AK, Cosgrove J. Salmonella typhi breast abscess: An uncommon manifestation of an uncommon disease in the United States. Am Surg. 2011;77:E133-5.
Cite this article as: Patel KP, Darne R, Poojary R, Kinjale V. Breast abscess due to Salmonella species: a brief review of epidemiology, clinical manifestations, serological correlation and management. Int J Community Med Public Health 2021;8:2077-80. 